\begin{tabular}{|c|c|c|}
\hline & Journal Homepage: - www.journalijar.com & $\begin{array}{l}\text { INTERNATIONAL JOURNAL OF } \\
\text { ADVANCED RESEARCH (IJAR) }\end{array}$ \\
\hline ISSN NO. 2320-5407 & $\begin{array}{c}\text { Article DOI: } 10.21474 / \text { IJAR01/3189 } \\
\text { DOI URL: http://dx.doi.org/10.21474/IJAR01/3189 }\end{array}$ & \\
\hline
\end{tabular}

\title{
RESEARCH ARTICLE \\ LIVER INVOLVEMENT IN SICKLE CELL TRAIT: A CASE CONTROL STUDY AMONG NEPALESE INDIGENOUS THARU COMMUNITY
}

\author{
Bhup Dev Bhatta ${ }^{1}$, Buddhi Bahadur Thapa ${ }^{2}$, Sunita Ranabhat ${ }^{1}$, Umesh Gupta ${ }^{3}$, Amrit Bhandari ${ }^{1}$, Mukunda \\ Kalaune $^{1}$, Alneil M. Hamza ${ }^{4}$, Mohammed H. Saiem Al Dahr ${ }^{5}$ and Dipendra Raj Pandeya ${ }^{4,6}$ \\ 1. Swastik Referral Laboratory and Research Centre, Pokhara, Nepal. \\ 2. Department of Internal Medicine, Gandaki medical college, Pokhara, Nepal. \\ 3. Pokhara University, Pokhara, Nepal. \\ 4. College of Applied Medical Sciences, Al Jouf University, Saudi Arabia. \\ 5. Department of Medical Laboratory Technology, Faculty of Applied Medical Sciences, King Abdulaziz \\ University, Jeddah, Saudi Arabia \\ 6. Department of Biochemistry, College of Medicine, Nepalese Army Institute of Health Sciences, Kathmandu, \\ Nepal.
}

\section{Manuscript Info}

Manuscript History

Received: 08 December 2016

Final Accepted: 13 January 2017

Published: February 2017

Key words:-

Sickle cell trait, liver function, total protein, AST, ALT, LDH, bilirubin

\section{Abstract}

Background: Sickle cell trait is not usually regarded as a disease state because it may present several types of health complications that are either uncommon or mild and have not been thoroughly investigated. This article aims to describe the relationship between sickle cell trait (SCT) and liver function test (LFT) parameters in tharu community of western tarai region of Nepal.

Method: Sixty two (62) subjects divided into control subjects $(\mathrm{n}=31)$ and heterozygous sickle cell patients $(n=31)$ were recruited for the study and were investigated for a liver function tests including the measurement of total protein, albumin, globulin, total bilirubin, direct bilirubin, indirect bilirubin, aspartate transaminase (AST), alanine transaminase (ALT) and lactate dehydrogenase (LDH) in both groups. Mean, Standard deviation, Students $T$ test analysis were used for analysis of results.

Result: The serum total protein, globulin, total bilirubin, indirect bilirubin, aspartate transaminase (AST), alanine transaminase (ALT) and lactate dehydrogenase (LDH) were significantly higher in SCT patients than in controls, with $\mathrm{P}$ values of $0.014,<0.001,0.003,0.006$, $<0.001,<0.001$ and $<0.001$ respectively. However, there were no significant difference in the mean value of albumin and direct bilirubin. There was strong correlation noticed between AST and LDH in the test group.

Conclusion: It appears that abnormal liver function tests in patients with sickle cell trait poses an uncertain threat for liver disease. The liver functions of the SCT patients were significantly compromised as compared to controls. Studies at molecular level are needed to understand the pathophysiology and progression of liver disease in sickle cell anemia. It is advisable that liver function tests be interpreted with caution in these patients.

Copy Right, IJAR, 2017,. All rights reserved. 


\section{Introduction:-}

Sickle cell disease is standout amongst the most common autosomal hereditary disorders, described by the presence of hemoglobin S (HbS). It is the most regular sort of hemoglobinopathy. The SCD can bring about various disorders that differ with respect to degree of anemia, recurrence of emergencies and in terms of survival [1]. So, the inconstancy in clinical seriousness from the virtually symptomless sickle cell trait to the conceivably lethal state of sickle cell anemia. Patients with SCD present with a broad range of phenotypic hemoglobin structures; they vary clinically from mild vaso-occlusive crises to severe clinical manifestations [2]. According to WHO data and statistics, SCD affects millions of people throughout the world. It is suggested that SCD is prevalent in malaria endemic areas because the sickle cell provides its carrier with resistance against malaria. It is most common among people whose ancestors come from Africa, Mediterranean countries such as Greece, Turkey, and Italy, the Arabian Peninsula, India and Spanish-speaking regions in South America, Central America, and parts of the Caribbean.

As with sickle cell disease, sickle cell trait is characterized by the inheritance of a single abnormal $\beta$-globin gene. Unlike sickle cell disease, however, the other $\beta$-globin chain is unaffected, enabling that chain to retain its functional and phenotypic properties. As such, those with sickle cell trait are generally mildly anemic or asymptomatic, reducing the likelihood of skeletal manifestation of the disease [3,4]. Traditionally, SCT has been viewed as a benign condition, a non-disease status, without any painful episodes that are characteristic of homozygous SCD. On a population basis, SCT has no discernible impact on life expectancy. There are more than 300 million carriers of sickle cell trait worldwide [5], with the highest prevalence of approximately $30 \%$ to $40 \%$ in sub-Saharan Africa. In Nepal, Tharu people are one of the oldest ethnic group indigenous to the Terai region. In 1990, WHO has reported that most of the Tharu communities in western region of Nepal are living with different hemoglobinopathies, SCD being commonest inherited disorder in this population.

Patients with sickle cell anemia/trait may experience the ill effects of an assortment of hepatic changes. The changes in the shape of red blood cells favors intravascular hemolysis and in this way impediment of the liver vascular bed, driving at last to tissue damage, yet more generally turns out as a result of the numerous transfusions that the patients require in their lifetime. Furthermore, hemolysis induces deposition of bilirubin causing intrahepatic cholestasis and cholelithiasis [6]. The incidence of liver disease in sickle cell disorders is difficult to ascertain despite being a component of the multiorgan failure that occurs in sickle cell disease [7]. This is because dysfunction of the liver in sickle cell disease is multifactorial [6] and the complications of hepatic dysfunctions are prominent and fatal in most of the cases [8].

Evidence of liver disease in sickle cell disease is obtained either from abnormal biochemical tests or postmortem liver biopsy specimen rarely an antemortem liver specimen. Abnormal liver function tests are noticed in patients with SCA, even in the absence of liver disease. So, this study therefore attempts to disclose the pattern of liver function tests (LFTs) in sickle cell trait patients in Tharu community of western tarai region of Nepal.

\section{Material and Methods:-}

Samples from 31 adult patients and 31 healthy controls of same age groups were taken from the tharu population of Phattepur, Baijapur and Binauna VDCs of Banke district were included in this study. The laboratory investigations were performed in the Laboratory at Bheri Zonal Hospital, Nepalgunj, Banke, and Swastika referral laboratory, Ramghat, Pokhara, Nepal. This study was carried out during 13 March to 18 March 2016. The study protocol was approved by the Institutional Ethical Committee. An informed written consent was obtained from all the study subjects who were enrolled in the study. Venous blood samples $(5 \mathrm{ml})$ were subjected to complete blood count (CBC), hemoglobin electrophoresis and liver function test profile. SCT was confirmed by hemoglobin electrophoresis pattern. The estimation of biochemical parameters such as total protein, albumin, AST, ALT, ALP, total bilirubin and direct and indirect bilirubin in serum was done by Human laboratory test kits in a semiautomated (Biolab) analyzer with dedicated reagents.

\section{Statistical Analysis:-}

The study data was analyzed by using SPSS program to compute descriptive parameters including mean and frequencies, and inferential statistics was used including student's $t$ test to test the significance of the differences between the mean values of two continuous variables and Chi-squire test $\left(\mathrm{X}^{2}\right)$ test the difference in proportions 
categorical variables between two groups. The level of confidence $(P<0.05)$ was considered as cutoff value for significance.

\section{Results:-}

Total protein, bilirubin and some enzymes were selected as biochemical parameters to shed light on the liver functions tests in patients with sickle cell disease. Comparison of the biochemical parameters means were computed for study and control groups.

Table1 shows the statistics of biochemical parameters computed for study and control groups which point out that ( total proteins, albumin and globulins) results were found to be $(7.6 \pm 0.7$ and $7.3 \pm 0.5, P=0.014),(4.1 \pm 0.5$ and $4.3 \pm 0.3, P=0.085)$ and $(3.5 \pm 0.6$ and $2.9 \pm 0.4, P<0.001)$ respectively.

At the same time (total bilirubin, direct and indirect bilirubin) results were $(0.9 \pm 0.2$ and $0.7 \pm 0.3, P=0.003)$, $(0.2 \pm 0.1$ and $0.2 \pm 0.1, P=0.161)$ and $(0.6 \pm 0.2$ and $0.5 \pm 0.2, P=0.006)$ respectively.

Also, enzymes results were AST (61 \pm 28.2 and $29 \pm 6.3, P<0.001)$, ALT $(62.9 \pm 40.4$ and $32 \pm 6.3, P<0.001)$ and LDH $(790.3 \pm 291.4$ and $303 \pm 57.9, P<0.001)$.

Table 2 shows the abnormal results of biochemical tests which indicate that two biochemical tests out of nine tests performed within study and control groups (albumin and direct bilirubin) shows normal result, on the other hand, the statistically insignificant abnormality of result shown by total protein and total bilrubin with percent of $(3.2 \%)$ and $(P=0.116, P=0.311)$ respectively.

Conversely, statistically significant abnormality of results in study and control groups shown by globulin and indirect bilirubin $(55 \%$ and $6.4 \%, P<0.001)$ and $(39 \%$ and $3.2 \%, P<0.001)$ respectively.

Enzymes results also, show statistically significant abnormality which were AST (68\% and 3.2\%, P<0.001), ALT (71\% and 6.4\%, $P<0.001)$ and LDH (100\% and 68\%, $P<0.001)$. Statistically significant association of 5 abnormal biochemical tests with sickle cell disease is depicted in (figure1).

Correlation was run to determine the relationship between $\mathrm{LDH}$ and other liver functions tests. There was only a positive correlation between LDH and AST, which was statistically significant $(r=.378, n=31, p=.031)$. This correlation is depicted in (figure 2).

Table 1:- Statistics of biochemical parameters in study and control groups

\begin{tabular}{|c|c|c|c|}
\hline Biochemical parameters & Study group $(\mathrm{n}=31)$ & Control group $(\mathrm{n}=31)$ & \multirow{2}{*}{ P-value } \\
\cline { 2 - 4 } & Mean \pm STD & Mean \pm STD & 0.014 \\
\hline Total protein & $7.6 \pm 0.7$ & $7.3 \pm 0.5$ & 0.085 \\
\hline Albumin & $4.1 \pm 0.5$ & $4.3 \pm 0.3$ & 0.000 \\
\hline Globulin & $3.5 \pm 0.6$ & $2.9 \pm 0.4$ & 0.003 \\
\hline Total bilirubin & $0.9 \pm 0.2$ & $0.7 \pm 0.3$ & 0.161 \\
\hline Direcet bilirubin & $0.2 \pm 0.1$ & $0.2 \pm 0.1$ & 0.006 \\
\hline Indirect bilirubin & $0.6 \pm 0.2$ & $0.5 \pm 0.2$ & 0.000 \\
\hline AST & $61 \pm 28.2$ & $29 \pm 6.3$ & 0.000 \\
\hline ALT & $62.9 \pm 40.4$ & $32 \pm 6.3$ & 0.000 \\
\hline LDH & $790.3 \pm 291.4$ & $303 \pm 57.9$ & 2 \\
\hline
\end{tabular}

Table 2:- Percentage of abnormal liver biochemical function tests and association between groups

\begin{tabular}{|l|c|c|c|c|c|c|}
\hline \multirow{2}{*}{ Biochemical parameters } & \multicolumn{2}{|c|}{ Study group } & \multicolumn{2}{c|}{ Control group } & \multirow{2}{*}{ X } \\
\cline { 2 - 6 } & Normal & Abnormal & Normal & Abnormal & & \\
\hline Total protein & 23 & $8(26 \%)$ & 30 & $1(3.2 \%)$ & 6.37 & 0.116 \\
\hline Globulin & 14 & $17(55 \%)$ & 29 & $2(6.4 \%)$ & 17.07 & 0.000 \\
\hline Total bilirubin & 28 & $3(10 \%)$ & 30 & $1(3.2 \%)$ & 1.07 & 0.311 \\
\hline Indirect bilirubin & 19 & $12(39 \%)$ & 30 & $1(3.2 \%)$ & 11.77 & 0.000 \\
\hline AST & 10 & $21(68 \%)$ & 30 & $1(3.2 \%)$ & 28.18 & 0.000 \\
\hline ALT & 9 & $22(71 \%)$ & 29 & $2(6.4 \%)$ & 27.19 & 0.000 \\
\hline LDH & 0 & $31(100 \%)$ & 10 & $21(68 \%)$ & 11.92 & 0.000 \\
\hline P value based on chi squire test $(p<0.05)$ significant
\end{tabular}




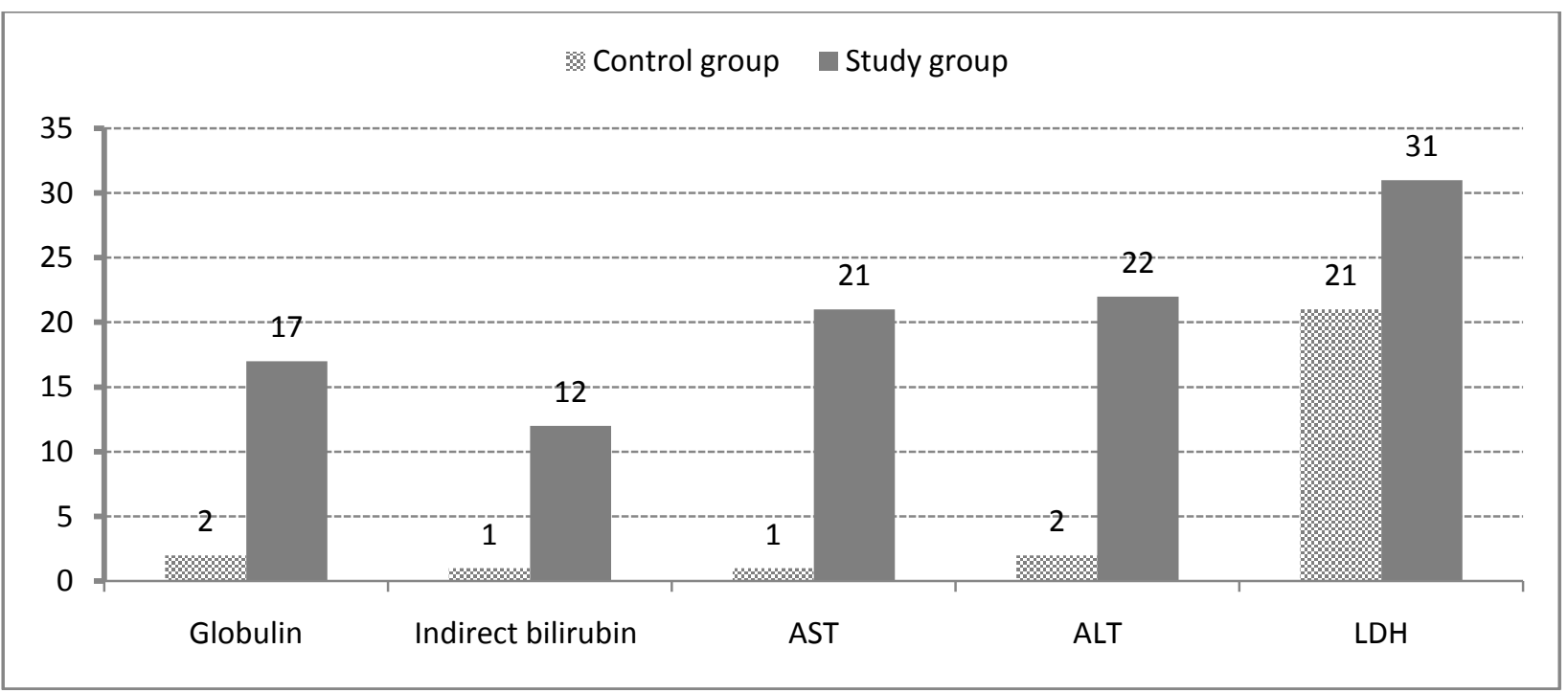

Figure 1:- Association of 5 abnormal biochemical tests with sickle cell disease.

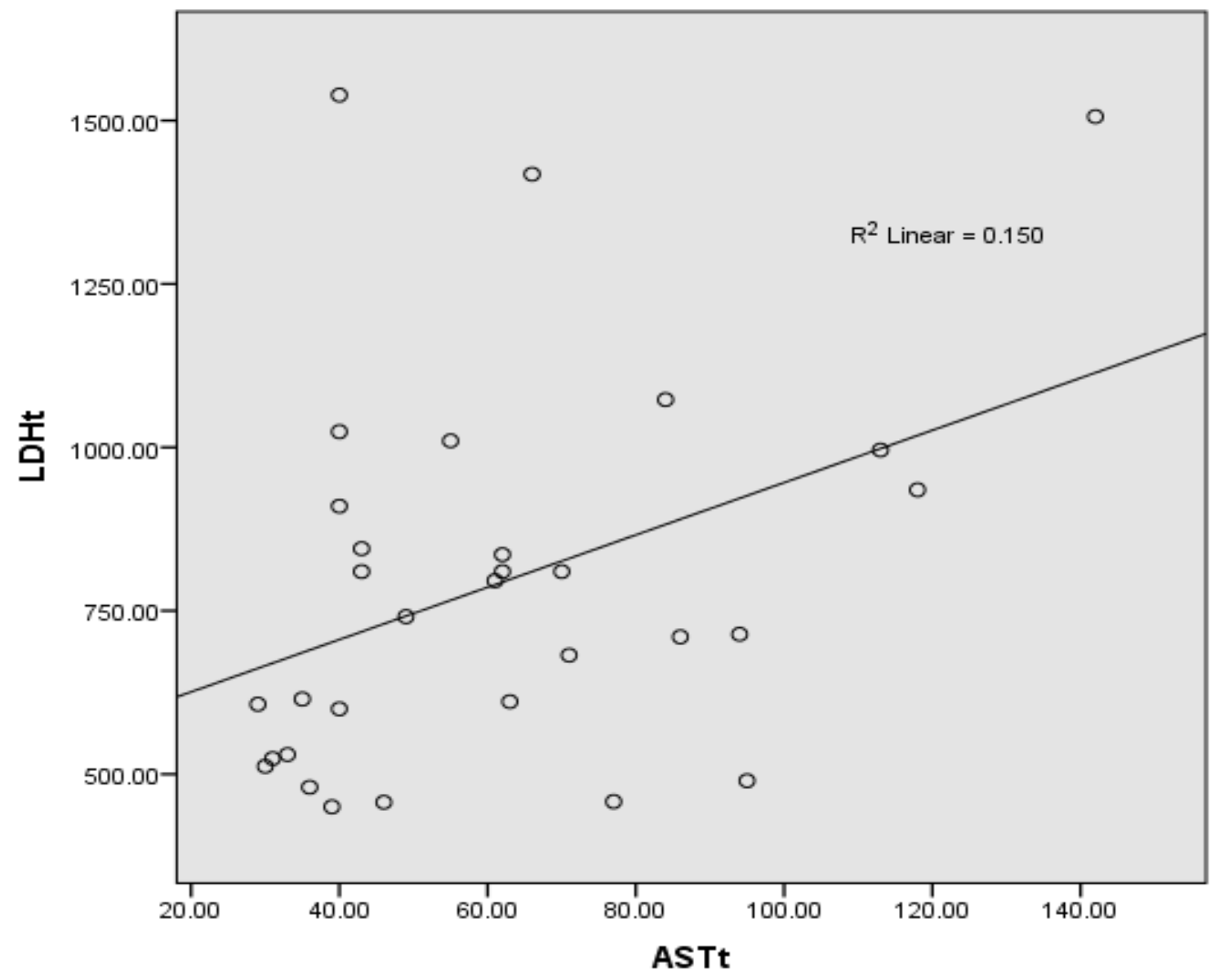

Figure 2:- Correlation between LDH and AST within study group 


\section{Discussion:-}

This study was designed to evaluate liver function tests (Total protein, albumin, globulin, total bilirubin, direct bilirubin, indirect bilirubin, AST, ALT and Lactate Dehydrogenase (LDH)) in patients with sickle cell trait. To achieve this aim, 31 patient's samples and 31 controls were analyzed. The findings of this study demonstrates a significant association of serum total protein, globulin, total bilirubin, indirect bilirubin, AST, ALT and LDH between sickle cell trait patients and controls groups. However, serum albumin and direct bilirubin showed no statistically significant difference. So, our study shares similar findings with Gardner K et al. 2014 and Mahera MM et al. 2009 [9,10]. These findings suggest that a multifactorial etiology can exist for occurrence of liver disease in SCA patients

In this study, out of 31 patients $71 \%$ were having increased alanine transaminase (ALT) level as compared to levels with control group. The increased ALT levels observed in this study confirms by the results of a number of studies $[11,12]$. On the other hand, out of the 31 cases $68 \%$ of the patients have aspartate transaminase level above normal value and only $32 \%$ patients have serum AST value within normal range. So, our study is comparable with studies by Johnson et al. 1985 [13]. Taiwo Kotila et al. 2005 reported that 50\% of the patients have aspartate transaminase level above normal limit [14].

It is well known that AST and ALT levels are commonly associated with 'Liver Function Test' (LFT) panel, but rather than assessing functions of the liver, the release of ALT and AST from liver cells to the bloodstream represents hepatocellular damage or death. The reason for deranged liver function appears to be the consequence of repeated vaso-occlusive episodes in sickle cell anemia or either due to widespread sickling within the sinusoid or due to extreme hemolysis [6]. Intrahepatic cholestasis is one of the fatal complications of sickle cell anemia. Sickling of red blood cells in hepatic sinusoids and their stasis may also cause serious damage to hepatocytes and Kupffer cells.

Another finding of this study was the higher LDH concentration observed in SCT patients. Our study revealed that $100 \%$ of the test groups were found the abnormal LDH value. Increased LDH have been reported in several previous studies of Sickle cell patients [15,16]. There is increasing evidence that lactate dehydrogenase (LDH) is a useful marker of intravascular haemolysis in adults with sickle cell anemia. It has emerged as the most useful marker of haemolysis-related complications of SCD. During vaso-occlusive episodes, LDH rises at least in part due to lysis of red cells but the increased $\mathrm{LDH}$ level is also due to lysis of cells from other organs.

Out of 31 cases total bilirubin and indirect bilirubin value above reference range were $10 \%$ and $39 \%$ of the test groups, which was statistically significant when compare with control groups. Gurkan E, et al. 2005 also reported hyperbilirubinemia in $13 \%$ of the patient [12]. Few studies report the elevation of bilirubin in sickle cell patients $[17,18]$. However, there was no significant association observed in direct bilirubin between the test and control groups. The difference in direct bilirubin levels is small and has been noted previously [13] and may represent haemoglobin load. Although there were no statistically significant differences, the levels are probably not of clinical relevance as the vast majority still fell within normal range. Derangement in concentration of bilirubin metabolizing enzymes in liver causes defective bilirubin metabolism that in turn result in increased serum bilirubin level. Hemolysis occurring in sickle cell disease is another reason for increased bilirubin level.

All the three patterns of proteins are altered in this study. A comparison of the serum protein values shows definite evidence of relative hyperproteinaemia as well as hyperglobulinaemia in test group. The total protein and globulin values in SCT were significantly greater than in normal, showing that the globulin fraction is largely accountable for the high total protein. The elevated gamma globulin is due to the extent of antigenic stimulation coming from the environment [19]. Whereas the albumin levels were not statistically promising in the test and control groups. This is in agreement with the work of Tripathi et al. 2011, who observed the low level of albumin in sickle cell disease patients [20] but in contrast with Famodu et al. 1987 who observed high level of serum albumin in sickle cell disease [21].

\section{Conclusions:-}

From above data and findings it could be concluded that liver functions of sickle cell trait patients is impaired. The most of the biochemical parameters of liver functions vary significantly from the normal subjects. So, sickle cell trait (SCT) patients are under the threat of hepatic dysfunction. On the basis of different biochemical parameters in 
the SCT patients it could be concluded that the liver of such patients are under risk and suffering from various complications and indicating that prevention and treatment of liver related disorders should approaches for Sickle cell disease. Further studies in a large patient population across multiple institutions and countries are needed to confirm the results of our study and to better understand the exact factors involved in liver function that contribute to the increased risk of Sickle cell disease and how the effects are mediated at a molecular level.

\section{References:-}

1. Luzzattol, (1981). Hemoglobinopathies including thalasamia.part 3 sickle cell anemia in tropical Africa. clin.hematol (10):757-84.

2. Adewoyin AS (2015) Management of sickle cell disease: a review for physician education in Nigeria (SubSaharan Africa). Anemia 2015: 21.

3. Kavanagh, P.L., P.G. Sprinz, S.R. Vinci, H. Bauchner and C.J. Wang. 2011. Management of Children with Sickle Cell Disease: A Comprehensive Review of the Literature. Pediatrics 128(6), e1552-74.

4. Serjeant, G.R. 2010. One Hundred Years of Sickle Cell Disease. British Journal of Haematology 151(5), 425-9.

5. Bunn HF. Pathogenesis and treatment of sickle cell disease. N Engl J Med1997;337:762-9.

6. Banerje e S, Owen C, Chopra S. Sickle cell hepatopathy. Hepatology 2001;33:1021-8.

7. Hassell KL, Eckman JR, Lane PA. Acute multiorgan failure syndrome: A potentially catastrophic complication of severe sickle cell pain episodes. Am J Med 1994;96:155-62.

8. Rosenblate HJ, Eisenstein R, Holmes AW. The liver in sickle cell anemia. A clinical- pathologic study. Arch Pathol 1970;90:235-45.

9. Gardner K, Suddle A, Kane P, O'Grady J, Heaton N,Bomford A, Thein SL. How we treat sickle hepatopathy and liver transplantation in adults. Blood 2014; 123:2302-2307.

10. Mahera MM, Mansour AH. Study of Chronic Hepatopathy in Patients with Sickle Cell Disease. Gastroenterology Research 2009; 2: 338-343.

11. Al-Suleiman AM, Bu-sobaih J; Acute fulminant cholestatic jaundice in sickle cell disease; Ann Saudi Med 2006;26(2): 138-140.

12. Gürkan E, Ergun Y, Zorludem«R S,Bafilamifili F, Koçak R; Liver involvement in sickle cell disease. Turk J Gastroenterol 2005; 16 (4): 194-198.

13. Johnson CS, Omata M, Tong MJ, Simmons JF Jr, Weiner J, Tatter D. Liver involvement in sickle cell disease. Medicine (Baltimore) 1985;64:349-56.

14. Kotila T, Adedapo k, Adedapo A, Oluwaslo O, Fakunle E, Brown B. Liver dysfunction in steady state sickle cell disease. Ann Hepatol 2005; 4(4):261-263.

15. Ballas SK. Lactate dehydrogenase and hemolysis in sickle cell disease. Blood. 2013; 3;121(1):243-4.

16. Neely CL, Wajima T, Kraus AP, Diggs LW, Barreras L. Lactic acid dehydrogenase activity and plasma hemoglobin elevations in sickle cell disease. Am J Clin Pathol. 1969;52(2):167-169.

17. Hargrove MD. Marked increase in serum bilirubin in sickle cell anemia. A report of 6 patients. Am J Dig Dis. 1970;15(5):437-42.

18. Isichef UP. Serum protein profile in sickle cell disease. J Clin Pathol. 1979;32:117-21.

19. Johnson AM, Rohif EM and Silverman LM (1999). Proteins. In Teitz Textbook of clinical chemistry (3 ${ }^{\text {rd }}$ edition). Ashwood ER, Butris CA (eds) WB Sanders Philadephia PP 350-615.

20. Tripathi S, Dadsena R, and Kumar A. Study of certain biochemical parameters in patients of sickle cell anemia. Adv. Biores. 2011;2(2):79-81.

21. Famodu AA, Omodiale P, Adedeji MO, and Reid HL. Serum protein study in adult Nigerians with sickle cell anemia. Med. Sci. Res. 1987;15:193-4. 